TEME, г. XLIV, бр. 4, октобар - децембар 2020, стр. 1549-1562

\begin{tabular}{lr}
\hline \hline Оригинални научни рад & https://doi.org/10.22190/TEME201008093K \\
Примљено: 8. 10. 2020 & UDK 821.111'282.3(414).09-1"19"
\end{tabular}

Ревидирана верзија: 5. 12. 2020.

Одобрено за штампу: 5. 12. 2020.

\title{
SCOTTISH LITERARY RENAISSANCE: FROM HUGH MACDIARMID TO TOM LEONARD, EDWIN MORGAN AND JAMES ROBERTSON ${ }^{a}$
}

\author{
Milena Kaličanin \\ University of Niš, Faculty of Philosophy, Niš, Serbia \\ milena.kalicanin@filfak.ni.ac.rs
}

\begin{abstract}
The paper deals with the Scottish literary revival that occurred in the 1920s and 1930s. The leading theoretical and artistic figure of this movement was Hugh MacDiarmid, a Scottish poet whose main preoccupation was the role of Scots and Gaelic in shaping modern Scottish identity. Also called the Lallans revival - the term Lallans (Lowlands) having been used by Robert Burns to refer solely to the notion of language, the movement's main postulates included the strengthened cultural liaisons between Scots and Gaelic (and not Scots and English as was the case until then). In the preface to his influential anthology of Scottish poetry, The Golden Treasury of Scottish Verse (1941), MacDiarmid bluntly stated that the prime aim of Scottish Literary Renaissance was to recharge Scots as a stage in the breakaway from English so that Scottish Gaelic heritage could properly be recaptured and developed. Relying primarily on MacDiarmid's theoretical insights, it is our purpose to track, explore and describe the Scottish Literary Renaissance's contemporary echoes. The paper thus focuses on the comparative analysis of Hugh MacDiarmid's poetry, on the one hand, and the poetry of its contemporary Scottish creative disciples (Tom Leonard, Edwin Morgan and James Robertson). By comparing and contrasting the selected poems of the aforementioned poets, the main goal of the paper is to emphasize the validity, relevance and actuality of MacDiarmid's movement for the present moment in Scotland.
\end{abstract}

Key words: $\quad$ Scottish Literary Renaissance, Scots, Gaelic, the Caledonian Antisyzygy, Scottish identity.

${ }^{a}$ This study was financially supported by the Ministry of Education, Science and Technological Development of the Republic of Serbia. 


\title{
ШКОТСКА КЫИЖЕВНА РЕНЕСАНСА: ОД ХЈУА МЕКДАРМИДА ДО ТОМА ЛЕНАРДА, ЕДВИНА МОРГАНА И ЏЕЈМСА РОБЕРТСОНА
}

\begin{abstract}
Апстракт
У раду се говори о шкотском књижевном препороду који се десио током касних двадесетих и раних тридесетих година XX века. Главна теоријска и уметничка фигура овог покрета био је Хју Мекдармид, шкотски песник чија је основна преокупација била улога шкотског и галског језика у обликовању модерног шкотског идентитета. Важни постулати овог правца тицали су се ојачања културних веза између шкотског и галског језика (а не шкотског и енглеског, како је до тада био случај). У предговору антологије шкотске поезије Благо шкотског стиха (1941), Мекдармид је отворено истакао да је основни циљ Шкотске књижевне ренесансе да се шкотски језик перципира као фаза у коначном удаљавању од енглеског како би се омогућио повратак и даљи развој шкотског галског наслеђа. Ослањајући се првенствено на Мекдармидове теоријске увиде, наш циљ је да откријемо, истражујемо и пратимо савремене одјеке Шкотске књижевне ренесансе. Рад се стога заснива на компаративној анализи одабране поезије Мекдармида и поезије његових савремених шкотских следбеника (Ленарда, Моргана и Робертсона) како би се нагласила валидност, релевантност и актуелност Мекдармидовог покрета за садашњи тренутак у Шкотској.
\end{abstract}

Кључне речи: Шкотска књижевна ренесанса, шкотски, галски, каледонијски поларитет, шкотски идентитет.

\section{INTRODUCTION: TOWARDS THE DEFINITION OF SCOTTISH LITERARY RENAISSANCE}

Scottish Literary Renaissance was a literary movement that initially happened during the late twenties and early thirties of the $20^{\text {th }}$ century. Though it is frequently linked to the $15^{\text {th }}-17^{\text {th }}$ Renaissance period in Scotland, the common denominator for these diverse cultural movements can solely be found in the literal translation of their mutual title, revival. The Renaissance in Scotland was a revival associated with the main principles of the pan-European Renaissance that primarily intended to restore humanism through the renewal of the interest in the classical era writing and the promotion of scientific investigation, logical reasoning, concepts of balance and proportion. The Scottish literary revival of the $20^{\text {th }}$ century partially relied on the governing pan-European Renaissance principles; however, it was predominantly preoccupied with the Scottish cultural heritage linguistics in particular.

Patrick Geddes, one of the leading figures in the Celtic Twilight movement that influenced a renewed interest in the diverse aspects of Celtic culture, coined the phrase the Scots Renaissance in 1895. This was the title of his article published in Evergreen, which pointed to the intense need to reawaken the spirit of Scottish cultural nationalism. However, it was in the work of a famous Scottish poet of the $20^{\text {th }}$ century, Hugh 
MacDiarmid, that the concept of the Scottish cultural revival achieved its practical realization. Namely, the main goals of the Scottish Literary Renaissance were exposed in the preface to The Golden Treasury of Scottish Verse (1941), an anthology of Scottish poetry that MacDiarmid edited. Its guiding ideas were related to hopeful liberation of Scotland from the prominent influence of English culture, the necessary break with the stereotypical sentimentalism of the Highlander tradition and the desirable promotion of international stands of Scottish culture in the 1920s and 1930s.

Apart from these issues, the movement's spokesperson, MacDiarmid, expressed a keen interest in the apparent diversity of the Scottish linguistic domain, so he straightforwardly stated in the preface to the aforementioned anthology that the conspicuous difference between his and other volumes of Scottish poetry lied in the fact that special attention was paid to the representation of Gaelic and Latin linguistic elements that he found crucial for the complete understanding of the Scottish experience (MacDiarmid, 1941 , p. x). Namely, the first decades of the $20^{\text {th }}$ century in Scotland were characterized by a prominent need to explore the role of Scots and Gaelic in shaping modern Scottish identity on the part of leading Scottish theoreticians, artists and thinkers. Thus, apart from the guiding cultural component, the movement was obviously based on strong political grounds, nationalism being one of the indispensable aspects of its discourse.

Scottish Literary Renaissance is nowadays also popularly called the Lallans revival. Although the term Lallans (Lowlands) was first used by Robert Burns in "Epistle To William Simson" $(1785)^{1}$ to refer to the notion of the Scots language as a whole, the movement's main postulates included the strengthened cultural liaisons between Scots and Gaelic (and not Scots and English as was the case until then). Thus, the linguistic diversity of the Scottish literary revival basically reflected diverse political options of its artistic representatives who mostly played an active role in various nationalist movements in Scotland at the beginning of the $20^{\text {th }}$ century.

\section{"SYNTHETIC SCOTS". ATTEMPT TO RECAPTURE SCOTTISH LINGUISTIC VITALITY}

The leading theoretical and artistic figure of Scottish Literary Renaissance Hugh MacDiarmid bluntly proclaimed that the prime aim of this movement was to recharge Scots as a stage in the breakaway from English, so that Scottish Gaelic heritage could properly be recaptured and developed (1941, p. xi). Though the national bard of Scotland, Robert

\footnotetext{
${ }^{1}$ They took nae pains their speech to balance, Or rules to gie;

But spak their thoughts in plain, braid lallans, Like you or me. (Burns, 2005)
} 
Burns, was constantly pleading for the revitalization of Scots through his verses, MacDiarmid felt that by favouring the cult of this exceptional $18^{\text {th }}$ century Scottish poet, great literary heritage had unjustly been neglected. Therefore, he proposed an intentional break away from the cult of Robert Burns and indispensable literary retrieval of the Scottish Makars ${ }^{2}$ from the $15^{\text {th }}$ and $16^{\text {th }}$ century such as Robert Henryson and William Dunbar (MacDiarmid, 1941, p. xxxvi, xxxvii). The poetic (particularly linguistic) expression of these extraordinary, but almost forgotten, Renaissance poets would further enable MacDiarmid for his own experiments with language.

Namely, MacDiarmid started with diverse linguistic experiments in his own verses in order to point to the inevitability of poetic expression in Scots that would exceed already imposed national barriers. Thus he selected a great number of words in Scots from John Jamieson's Etymological Dictionary of the Scottish Language (1808) and used them in his poems. Henryson's and Dunbar's poetry served the purpose of being a fertile ground of innovative expression in Scots, so he derived some words from the already existing linguistic heritage and gave them a new poetic form. It is also interesting to note that MacDiarmid intentionally invented new words in Scots in order "to bridge the gaps of a historically fragmented and stigmatized language" (Fiasson 2018, p. 4). Although this linguistic expression was rather artificial, MacDiarmid successfully managed to lay the groundwork for "the expression of poetry in Scots firmly set within an international and modern context" (Fiasson 2018, p. 4). This experimental vernacular style that MacDiarmid used in his poetry is nowadays referred to as the concept of "Synthetic Scots":

"Synthetic Scots" is not simply an attempt to valorize the Scottish language in spite of the necessary inauthenticity of such a project, nor, on the other hand, is it a personal invention of MacDiarmid's; it is rather a strategy by which Scots (of all kinds) can be remobilized to produce a new kind of poetic language whose characteristics are an effect of, and effect, the political and ideological structure in which MacDiarmid's work is situated. (Grant, 1992, p. 198)

\footnotetext{
${ }^{2}$ Makar: the equivalent of English maker, a term from Scottish literature referring to a poet or bard. In the first decades of the $20^{\text {th }}$ century Robert Burns $(1759$ - 1796) was popularly referred to as the first Scottish national bard. It was precisely this practice of praising solely Burns as the national poet of Scotland that made MacDiarmid point to a neglected Scottish literary tradition of the $15^{\text {th }}-17^{\text {th }}$ century. Hence his poetic slogans: "Not traditions precedents! Not Burns - Dunbar!” (BBC Two Writing Scotland, 2019) These slogans implied a necessary restoration of Scottish literary past in order to completely comprehend its present and empower its future artistic expression. In 2004, the Scottish Parliament established the position of national laureate, entitled the Scots Makar. Edwin Morgan was then proclaimed to be Scotland's official national poet, following in Burns's footsteps. In 2011, the post was granted to Liz Lochhead. Jackie Kay has held this relevant post since 2016 when she was announced as the third national bard of Scotland in the 21st century.
} 
The culmination of MacDiarmid's linguistic experiment can be found in his poem "A Drunk Man Looks at the Thistle" (1926). The poem is rather complex, written in the form of a long dramatic monologue containing 2685 lines. The poet describes a popular Scottish stereotype of a drunk man who finds himself lying on a moonlit hillside staring at a thistle. This jaggy but extremely beautiful national plant emanates the divided Scottish self. In his intoxication, the drunk man approaches the Scottish national flower and contemplates the fate of the Scottish nation, human condition in general and his own fears and worries in particular. "There's nocht sae sober as a man blin' drunk" (MacDiarmid, 1992), claims this village drunk, the prototype of a Scots Everyman.

A potent truth of the drunk man's visionary experience is fully contained in the thistle that is perceived in the poem both as a "wretched weed" and the emblem of Scottish stamina. The most significant aspect of the Scottish national plant blooming is the potency of the Scots language that MacDiarmid retrieved from the Scottish admirable past. Thus MacDiarmid's drunk man bluntly asserts that the prime function of Scottish poetry (that is, literature in general) is to bring back the long gone unity of Scotsmen through the medium of Scots:

The function, as it seems to me,

O' Poetry is to bring to be

At lang, lang last that unity. (MacDiarmid, 1992)

Although MacDiarmid's use of Scots is rather opaque in this poem, it "made a renewed claim for the validity of Scots as a contemporary literary language, and thus for the definition of a place for Scotland and Scottish culture in the international artistic spectrum" (Matthews and Riach, 2005, p. 127). For MacDiarmid, the publication of this poem represented the sole way to support the validity of the Scottish Literary Renaissance and yet again point to "the linguistic anomaly that the primary language of Scottish literature had become English, a language which he believed could not adequately express the breadth and particularity of the Scottish psyche" (BBC Two Writing Scotland, 2019).

Apart from MacDiarmid's preface to The Golden Treasury of Scottish Verse (1941) which is nowadays regarded as the manifesto of the Scottish Literary Renaissance, he constantly emphasized the need to revitalize Scottish linguistic heritage in his essays, public speeches, lectures, political activities, etc. Thus, in his influential essay, "English Ascendancy in British Literature", first published in T. S. Eliot's The Criterion in 1931, MacDiarmid straightforwardly argues that "the problem of the British Isles is the problem of English Ascendancy" (MacDiarmid, 1992, p. 63) and optimistically asserts that the revival of national cultural production that "has happened in Ireland can also happen in Scotland and Wales" (MacDiarmid, 1992, p. 77). He identifies three "conditions for the success 
of a Renaissance movement" in Scotland: "a rising tide of Scottish national consciousness"; "a thorough-going reorientation, in our schools and universities and elsewhere, on the study of Scottish Literature"; and "the necessity to bridge the gulf between Gaelic and Scots" (MacDiarmid, 1992, p. 73).

These conditions were central to the Scottish Literary Renaissance movement, although there was an artistic fraction led by another famous Scottish poet, Edwin Muir, who openly disagreed with MacDiarmid and had no preference for linguistic experiments with Scots, but accepted the language in Scotland as it had developed through time. This basically means that Muir continued to write his verses in English, arguing for its exclusive use in Scottish literature:

[...] a Scottish writer who wishes to achieve some approximation to completeness has no choice except to absorb the English tradition, and that if he thoroughly does so his work belongs not merely to Scottish literature but to English literature as well. [...] The prerequisite for an autonomous literature is a homogeneous language. (Muir, 1982, p. 4, 7)

Edwin Muir's basic concern was the idea of Scottish political reconstruction, based on international and not national standards. For instance, when he refers to Scottish history in his poem "Scotland 1941", Muir exclaims that "we were a tribe, a family, a people," owing to the relenting sense of unity formed by national heroes like Wallace and Bruce. However, he also states that the same features that define and constitute the Scottish identity - "courage beyond the point and obdurate pride" - actually "robbed us of a nation" and that proud defiance, as the most striking national characteristic, eventually evolved into national damnation (Muir, 1963, p. 58). The negative influence of the Scottish history on the nation is depicted in the poem through the notion of the lost national identity, by alluding to the ever-growing importance of material acquisition whereby the modern successor of a once valiant tribe and family "is a hoax produced by a kind of false consciousness masking its participation in British imperialism" (Robichaud, 2005, p. 145) and the lack of "the sense of community which would give meaning to the poet's bardic role" (Robichaud, 2005, p. 146).

A more optimistic vision of the Scottish nation is definitely presented in MacDiarmid's verses. In his poem "Scotland Small?", MacDiarmid refers to the common misconception of Scotland as a country in which one can find "nothing but heather" and regards it as "marvellously descriptive", but, at the same time, "incomplete" (MacDiarmid, 1987, p. 34). Thoroughly mindful of the strong impact of historical and nationalistic "loose ends", requiring "great love" on the part of the poet to openly accept, name and identify with them, MacDiarmid sets himself on the quest of depicting his native land's wholeness, which certainly offers a lot more than the pessimistic, gloomy and bleak image of the Scottish future depicted in Muir's poetry: 
So I have gathered unto myself

All the loose ends of Scotland,

And by naming them and accepting them,

Loving them and identifying myself with them,

Attempt to express the whole. (MacDiarmid, 1987, p. 41)

MacDiarmid's way of gathering "loose ends of Scotland" was related to the use of synthetic Scots in his poetry in order to recapture Scottish linguistic vitality. However, he was not persistent with this practice and by the end of his career he mostly wrote poetry in English (though this was his bone of contention with Muir). Completely aware of his linguistic inconsistency he wrote the poem "The Caledonian Antisyzygy" (1949) in which he tried to clarify this personal anomaly:

I write now in English and now in Scots

To the despair of the friends who plead

For consistency; sometimes achieve the true lyric cry,

Next but chopped-up prose; and write whiles

In traditional forms, next in a mixture of styles.

So divided against myself, they ask:

How can I stand (or they understand) indeed?

(MacDiarmid, 2004, p. 230)

MacDiarmid's here alludes to the historical animosity between English and Scots as two divided forms of expression. This division is ultimately contained within the poet himself and is further illustrated in the poem with his inability to opt for one linguistic option only. It is even reflected in the case of the poet's own stylistic preferences - should he settle for traditional forms or a mixture of styles? This inner split represents a good example of what the literary critic G. Gregory Smith termed "The Caledonian Antysyzygy" (that MacDiarmid symbolically refers to in the title of his poem), or the Scottish Antithetical Mind, the term based on the merging of opposing or paradoxical viewpoints typical of Scottish character. ${ }^{3}$

\footnotetext{
${ }^{3}$ Although this national trait is not unique to the Scots, it is definitely among the Scots that this contradiction becomes apotheosized, claims Scottish culture scholar Finlayson, who quotes from Smith:

Perhaps in the very combination of the opposites, "the Caledonian Antysyzygy", we have a reflection of the contrasts which the Scot show at every turn, in his political and ecclesiastical history, in his polemical restlessness, in his adaptability which is another way of saying that he has made allowance for new conditions, in his practical judgment, which is the admission that two sides of the matter have been considered. If therefore Scottish history and life are, as an old northern writer said of something else, 'varied with a clear contrair spirit', we need not be surprised to find that in his literature the Scot presents two aspects which appear contradictory. Oxymoron was ever the bravest figure, and we must not forget that the disorderly order is order, after all. (Finlayson, 1988, p. 22)
} 
Quite symbolically, the main linguistic dispute of Scottish Literary Renaissance leading figures has become internalized in MacDiarmid's verses. The fact is that both of them used English in their poetry but for different ends: for Muir, it represented the path towards unavoidable internalization of Scotland, whereas for MacDiarmid it was a clear example of his divided self as a result of hideous English ascendancy. This linguistic dispute testified to the existence of sharply contrasted individual visions of Scottish Literary Renaissance on the part of MacDiarmid and Muir that could not possibly be resolved. As a matter of fact, the two of them were never reconciled after 1936. However, as Fiasson claims, although the linguistic expression of the Scottish Literary Renaissance representatives differed, it is a fact that they operated on the margins of the English artistic and literary frames:

Similarly to Robert Burns and Walter Scott in the eighteenth and nineteenth centuries, the use of the languages of Scotland represented an act of cultural resistance. But in the twentieth century, Scotland's linguistic diversity was underpinned by the claims to political autonomy and independence promoted by nascent nationalist organisations. As a result, the linguistic flexibility gave the Scottish modernists ... an idiom that contributed to the cultural reclamation of Scotland's political identity through processes of national construction and deconstruction. (Fiasson, 2018, p. 8)

Whether the processes of national construction and deconstruction have proved significant for the cultural reclamation of Scotland's political identity will be discussed in the following segment of the paper that deals with the actuality of MacDiarmid's cultural and political legacy.

\section{SCOTTISH LITERARY RENAISSANCE'S CONTEMPORARY ECHOES}

Perhaps the best way to track, explore and describe Scottish Literary Renaissance's contemporary echoes is to focus on the selected poetry of its contemporary Scottish creative disciples (Tom Leonard, Edwin Morgan and James Robertson). It is precisely in the poetry of the aforementioned contemporary Scottish poets that the validity, relevance and topicality of MacDiarmid's cultural movement for the present moment can be perceived.

Watson claims that MacDiarmid's propaganda for the use of Scots to counter the hegemony of the standard English language has been of immense importance to the $20^{\text {th }}$ century Scottish writing (2006, p. 163). However, whereas MacDiarmid honestly admits by the end of his writing career that the core of his poetic expression lies in his inner incongruence reflected through the personal inability to choose between the sole use of English or Scots in his poetry, thus frequently combining these two means of expression, Tom Leonard, a renowned Scottish poet from the second half of the $20^{\text {th }}$ century, seems to have no problems in choosing a 
single option. He opts for the Glaswegian dialect of Scots, the language of frequently marginalized working class. His poetry thus echoes the first phase of the Scottish Literary Renaissance and MacDiarmid's constant pleas for the return to the roots of genuine Scottish culture reflected through the use of Scots in creative writing. Though, as Watson validly notices, Leonard would strongly disagree with MacDiarmid's political nationalism (2006, p. 163).

The main theme in Leonard's collection of poetry Intimate Voices: Selected Poetry (1965-1983) is the idea of polyphony or plurality of voices in modern Scottish society. Instead of concentrating on the ideologically, allpowerful monophony, Leonard gives the voice to the marginalized groups in Scotland whose linguistic expression has frequently been underestimated and undervalued. Although he had undergone a formal education and had been taught the classical rules of writing poetry in English, his view was that these could not convey the inner core of his artistic being. In "Poetry", he directly asserts: "that was my education/ and nothing to do with me" (Leonard, 1984, p. 62).

Instead of standard English, Leonard purposefully uses the Glaswegian Scots in order to show that it is not "disgraceful" as is the majority's opinion. In the poem "right inuff ma language is disgraceful", Leonard complains about the contempt that the use of Scots in his poetry provokes among the institutional pillars of modern Scottish society ("maw, techer, doactir, boss, literati, even the introduction to the Scottish National Dictionary"). In other words, writing poetry in standard English represents an easy way to success according to the opinion of his mother, teachers, a great majority of educated people, etc. However, in the manner of a socially engaged activist, he proudly proclaims that he does not want to compromise with his individual choices:

ach well

all livin language is sacred

fuck thi lotta him (Leonard, 1984, p. 65)

This is an illustration of the poet's sincere opposition to what he sees as the inherently ideological role of the educational system. Leonard wrote more about in the introduction to the anthology of poetry he edited, Radical Renfrew:

The important word is code. To understand Literature is to understand a code, and the teacher is the person trained to possess the code that Literature is in. This has to be accepted unconditionally, as it is the sole basis of the teacher's power to grade pupils' responses. A piece of writing that does not acknowledge the code that the teacher has been trained to possess, can not be accepted as Literature: for such writing deprives the teacher of the only basis of his power of assessment. This applies even when the 'canon' has been enlarged to 'allow' some writing about, for instance, working-class lives. (Leonard, 1990, p. ix) 
Perhaps the most poignant criticism of the position of working class representatives and their usage of Scots in modern Scottish society is presented in Leonard's poem "thi six a clock news" in which the poet strongly protests against the uniformity of truth presented through the powerful media of the BBC. The poem is based on the outburst of a representative of the Glaswegian working class, stating that the truth that is being daily broadcast via the BBC at six o'clock definitely cannot be the truth about his language, class and ultimately, culture.

In this poem a hypothetical situation is described: a BBC newsreader explains that if he read the news in the Glaswegian dialect, no one could believe that what he had been informing the people about was true. The implication of this ideologically dangerous utterance is that there is only one proper way of speaking and spelling, so the people who do not abide with standardized forms of expression are totally ignorant of the truth. This is a cause for the major irritation on Leonard's part. He can't stand the habit of the 'toffs' who depreciate his working class compatriots. He is also irritated with the working class representatives for allowing the 'posh' linguistic minority to dismiss them as inferior on the basis of their accent. This is probably the reason he finishes his poem with a rather colloquial outcry "belt up", meaning "shut up", since colloquialisms are strictly forbidden on the BBC. Leonard's opinion is that Scots cannot be perceived as "the language of the gutter", but is quite appropriate for reading the news and expressing the truth. The poet's anger with the devaluation of Scots is seen in the form of the poem whose structure is based on unbroken verse with no punctuation except a few full stops. His final intention is thus to question the readers' prejudices about the standardized version of a proper language.

Similarly, the first Scots Makar in the $20^{\text {th }}$ century, Edwin Morgan, pleads for the plurality and heterogeneity of diverse language experiences in his poetry. Perhaps the best poem from Morgan's wide poetic opus that illustrates the aforementioned idea is "The First Men on Mercury" (1973) that depicts a hypothetical situation in which Morgan describes a dialogue between the Earth explorers arriving on the planet Mercury and the Mercury's natives. The Earth men's intention is to colonize this planet; they feel superior to the civilization they found there. The alleged superiority of the Earth men is in the poem portrayed solely through the use of language: namely, the language that the Mercury's natives use is totally incomprehensible, abiding in rather primitive, onomatopoeic sounds. However, it gradually infects the Earth men, whereas the Mercurians gradually begin to adopt and apply English words and phrases in their communication.

Morgan's depiction of the long-lasting feud between England and Scotland, here basically presented through the medium of linguistic expression is rather relevant. It relies on MacDiarmid's insights about Scots and furthers his theory with the humorous portrayal of it as the alien 
language which implies that Scots are generally perceived as aliens in the UK. Another implication in the poem is that of English colonization of Scotland, but it merely depicts its linguistic aspect.

Unlike Leonard who is furious with the fact that Scots is depreciated, Morgan pleads for a sort of linguistic reconciliation. A sudden linguistic fusion happens in the situation when two distinct cultures, as well as two different languages are exposed to each other. The process of unconscious acquisition of the other culture diverse language features takes place and it contributes to the creation of a specific cultural mosaic. The poet ends his poem with a significant statement: "You'll remember Mercury" (Morgan, 2000 , p. 69). This statement points to the necessity of mutual cultural dependence. Though there has been a conspicuous historical, political, economic and ultimately, linguistic animosity between England and Scotland, the immutable fact is that both cultures acquired specific linguistic traits from each other. In Morgan's poem this process is described through the gradual change of language on the part of both Earth men and Mercurians; namely, the language of the Earth men changes under the influence of the Mercurians and becomes more incomprehensible and vice versa, the language of the Mercurians changes under the influence of the Earth men and becomes more comprehensible. The end of Morgan's poem thus testifies to the mutual cultural bond, or interdependence between English and Scots, difficult to be obliterated.

This is another trait that makes Morgan a proper disciple of MacDiarmid in his prime when he acknowledged his personal "Caledonian Antizysygy". In the aforementioned poem, Morgan alludes to the special history of the Scots language and culture that has made this linguistic bond possible and identifies it not as a shortcoming, but as an advantage. This cultural benefit is perhaps best summarized in Watson's words:

So MacDiarmid's notion of the 'double tongue' as a hindrance must be re-identified as an asset. The real 'doubling' in Scots stems from its closeness to English, and from what, over the years, has become the sociolinguistic and cultural inseparability of the two languages by way of a need to constantly re-invent and restate their mutually defining differences. (Watson, 2006, p. 174, 175)

The reconcilable tone permeating Morgan's poetry is not to be found in James Robertson's work. He is a proper creative disciple of MacDiarmid in spreading the idea of Scottish political nationalism through his verses. The prominent sense of national pride represents a constant in both Robertson's political outlook and creative work. It goes hand in hand with the potent wave of optimism he experienced regarding the issue of Scottish political future after the 1997 Devolution Referendum. It is most conspicuously seen in his wonderful poem "A Manifesto for MSPs" in Voyage of Intent written in Scots. A potent message that Robertson sends to the members of Scottish Parliament is to "seek oot the truth and tae the truth be leal" (Robertson, 
2005, p. 21). It serves the function of both a political manifesto and a means of connection to Scotland's rich literary and linguistic heritage. For Robertson, the new Scottish Parliament did not only represent an impressive building, but "a voyage of intent, a journey to whatever we might be" (Robertson, 2005, p. 24), as he claimed in another poem from the same collection, symbolically entitled "The Voyage". The poet's heartfelt idealism is potently captured in the poem's closing lines:

This is our new departure, this is what we opted for, solid and permanent, yet tenuous with possibility. (Robertson, 2005, p. 24)

Robertson's enthusiasm for the future prospects of independent Scotland has obviously decreased after the unexpected failure of the Scottish Referendum for Independence in 2014. However, his genuine belief, resembling that of MacDiarmid at the very beginning of Scottish Literary Renaissance, in writing in Scots as a political act of resistance has persevered as a potent reminder of the nation's awareness of cultural heritage and its significance for ensuing patriotic endeavors.

\section{CONCLUDING REMARKS}

Scottish Literary Renaissance, a cultural movement that marked the first half of the $20^{\text {th }}$ century, was mostly based on the issues of language and identity. The governing idea of MacDiarmid, the main spokesman of the movement, was to retrieve Scots and Gaelic in order to oppose English ascendancy and recreate, as well as develop proper Scottish national identity. Although in theory he pleaded for the sole use of Scots in creative writing, his late poems show that his poetic ideas could only be expressed in the interplay of Scots and English. His personal poetic incongruence serves as a proper illustration of the concept of "Caledonian Antisyzygy".

MacDiarmid's legacy regarding questions of language and identity still haunts the work of contemporary Scottish poets. When discussing contemporary poetry in Scots, Watson argues that

the linguistic pluralism inherent in Scottish cultural identity - in that original interplay between Scots, English and Gaelic - has made writers in Scotland peculiarly sensitive to how subjectivity is simultaneously constructed and undone in the precisions and imprecisions of language and in the tangled translations and transitions (and the political and social complexities) between utterance and reception. (Watson, 2006, p. 163)

The contemporary echoes of MacDiarmid's beliefs, succinctly expressed in Watson's quote, are rather conspicuous in the selected poetry of Leonard, Morgan and Robertson. Leonard pleads for linguistic polyphony and chooses to express his poetic being in Scots only; Morgan pleads for 
a sort of a linguistic reconciliation; Robertson is a proper disciple of MacDiarmid in terms of his political nationalism. However, as Watson shrewdly notices, these issues, though still relevant for modern Scottish poets, are not merely raised for the sake of recreating national identity or cherishing ancient literary heritage: "If identity is an issue among contemporary Scottish writers it is more likely now to be framed in the contexts of personal, existential, political or sexual being" (Watson, 2006, p. 163). In other words, MacDiarmid's legacy is still alive and influential, but modern Scottish poetry reflects a myriad of diverse contemporary issues that outreach this poet's rather challenging nationalist outlook.

\section{REFERENCES}

BBC Two Writing Scotland. Hugh MacDiarmid. (2019). https://www.bbc.co.uk/ programmes/profiles/60m5vt5DBNq4q02PQtpFqzq/hugh-macdiarmid

Burns, R. (2005). Epistle to William Simson. In Poems and Songs of Robert Burns. EBook. Project Gutenberg. https://www.gutenberg.org/files/1279/1279-h/1279-h.htm

Fiasson, A. (2018). The Role of the Scottish Renaissance in the (Re)construction of a Multilingual Identity Reverberating Internationally. Études écossaises [Online]. 20 | 2018. http://journals.openedition.org/etudesecossaises/1396

Finlayson, I. (1988). The Scots. Oxford: Oxford University Press.

Grant, R. (1992). Synthetic Scots: Hugh MacDiarmid's Imagined Communit. In N. Gish (ed.). Hugh MacDiarmid: Man and Poet. Edinburgh: Edinburgh University Press. 191-206.

Leonard, T. (ed.) (1990). Radical Renfrew: Poetry from the French Revolution to the First World War. Edinburgh: Polygon.

Leonard, T. (1984). Intimate Voices (1965-1983). Glasgow: Vintage.

MacDiarmid, H. (2004). Selected Poetry. Fyfield Press.

MacDiarmid, H. (1992). A Drunk Man Looks at the Thistle. In A. Riach and M. Grieve (eds.) Selected Poetry. New Directions Publishing Corporation. https://www.amazon.com/Selected-Poetry-Hugh-MacDiarmid/dp/185754756X

MacDiarmid, H. (1992). English Ascendancy in British Literature [1931]. In A. Riach (ed.) Selected Prose. Manchester: Carcanet. 61-80.

MacDiarmid, H. (1987). Collected Poems. London: Faber and Faber.

MacDiarmid, H. (ed.) (1941). The Golden Treasury of Scottish Verse. New York: The Macmillan Company.

Matthews K., A. Riach. (2005). A Drunk Man Looks at the Thistle. The Literary Encyclopedia. https://www.litencyc.com/php/sworks.php?rec=true\&UID=10057

Muir, E. (1963). Collected Poems. London: Faber and Faber.

Morgan, E. (2000). New Selected Poems. Manchester: Carcanet Press Limited.

Robichaud, P. (2005). MacDiarmid and Muir: Scottish Modernism and the Nation as Anthropological Site. Journal of Modern Literature, 28 (4), 135-151.

Robertson, J. (2005). Voyage of Intent: Sonnets and Essays from the Scottish Parliament. Edinburgh: Scottish Book Trust and Luath Press.

Watson, R. (2006). Living with the Double Tongue: Contemporary Poetry in Scots. In The Edinburgh History of Scottish Literature, Volume Three: Modern Transformations: New Identities (from 1918). Edinburgh: Edinburgh University Press. 163-175. 


\title{
ШКОТСКА КЫИЖЕВНА РЕНЕСАНСА: ОД ХЈУА МЕКДАРМИДА ДО ТОМА ЛЕНАРДА, ЕДВИНА МОРГАНА И ЏЕЈМСА РОБЕРТСОНА
}

\author{
Милена Каличанин \\ Универзитет у Нишу, Филозофски факултет, Ниш, Република Србија
}

\section{Резиме}

У првом делу рада уводи се појам Шкотске књижевне ренесансе, који се превасходно везује за процват шкотског књижевног стваралаштва током касних двадесетих и раних тридесетих година XX века. Иако првобитно осмишљен као искључиво књижевни покрет, приликом покушаја дефинисања његових основних карактеристика указује се на значај доминантних националних обележја, нарочито у лингвистичком домену. Песник Хју Мекдармид, један од оснивача овог покрета, истицао је важност често до тада запостављеног или маргинализованог шкотског и галског лингвистичког израза, те је кроз своју поезију тежио да се ојачају културне везе између ових језика (а не шкотског и енглеског, како је до тада био случај). У предговору антологије шкотске поезије „Благо шкотског стиха” (1941), Мекдармид је отворено истакао да је основни циљ Шкотске књижевне ренесансе да се шкотски језик перципира као фаза у коначном удаљавању од енглеског како би се омогућио повратак и даљи развој шкотског галског наслеђа. Мекдармидови теоријски увиди представљају почетну тачку истраживања савремених одјека Шкотске књижевне ренесансе. Након анализе неколико његових песама у којима се разматра употреба тзв. синтетичког шкотског језика, који нам пружа увид у политичку и идеолошку компоненту Мекдармидовог стваралаштва, у раду се даје преглед одабране поезије савремених следбеника Шкотске књижевне ренесансе (Ленарда, Моргана и Робертсона). У закључку рада наглашава се валидност, релевантност и актуелност Мекдармидовог покрета за тренутну политичку ситуацију у Шкотској. 